\title{
NADPH Oxidase-Derived Reactive Oxygen Species Mediate the Cerebrovascular Dysfunction Induced by the Amyloid $\beta$ Peptide
}

\author{
Laibaik Park, ${ }^{1}$ Josef Anrather, ${ }^{1}$ Ping Zhou, ${ }^{1}$ Kelly Frys, ${ }^{1}$ Rose Pitstick, ${ }^{3}$ Steven Younkin, ${ }^{2}$ George A. Carlson, ${ }^{3}$ and \\ Costantino Iadecola ${ }^{1}$ \\ ${ }^{1}$ Division of Neurobiology, Department of Neurology and Neuroscience, Weill Medical College of Cornell University, New York, New York 10021 , ${ }^{2}$ Mayo \\ Clinic Jacksonville, Jacksonville, Florida 32224, and ${ }^{3}$ McLaughlin Research Institute, Great Falls, Montana 59405
}

\begin{abstract}
Overproduction of the amyloid $\beta(\mathrm{A} \beta)$ peptide is a key factor in the pathogenesis of Alzheimer's disease (AD), but the mechanisms of its pathogenic effects have not been defined. Patients with $A D$ have cerebrovascular alterations attributable to the deleterious effects of $A \beta$ on cerebral blood vessels. We report here that NADPH oxidase, the major source of free radicals in blood vessels, is responsible for the cerebrovascular dysregulation induced by $\mathrm{A} \beta$. Thus, the free-radical production and the associated alterations in vasoregulation induced by $\mathrm{A} \beta$ are abrogated by the NADPH oxidase peptide inhibitor gp91ds-tat and are not observed in mice lacking the catalytic subunit of NADPH oxidase ( $\mathrm{gp}^{9}{ }^{\text {phox }}$ ). Furthermore, oxidative stress and cerebrovascular dysfunction do not occur in transgenic mice overexpressing the amyloid precursor protein but lacking gp91 ${ }^{\text {phox }}$. The mechanisms by which NADPH oxidase-derived radicals mediate the cerebrovascular dysfunction involve reduced bioavailability of nitric oxide. Thus, a gp91 ${ }^{\text {phox }}$-containing NADPH oxidase is the critical link between $A \beta$ and cerebrovascular dysfunction, which may underlie the alteration in cerebral blood flow regulation observed in $A D$ patients.
\end{abstract}

Key words: Alzheimer's disease; hydroethidine; gp91 ${ }^{\text {phox; }}$ Tg2576; cerebral blood flow; reactive oxygen species

\section{Introduction}

There is increasing evidence that Alzheimer's disease $(\mathrm{AD})$ is mediated by overproduction of the amyloid $\beta(\mathrm{A} \beta$ ) peptide, a cleavage product of the amyloid precursor protein (APP), but the mechanisms by which $A \beta$ leads to the disease have not been established (Selkoe and Schenk, 2003). Converging lines of evidence suggest that cerebrovascular factors play a key role in the pathogenesis of AD (Iadecola, 2004). Cerebral blood flow (CBF) is reduced in the early stages of $\mathrm{AD}$, and the reactivity of cerebral blood vessels is impaired (Prohovnik et al., 1988; Hock et al., 1997; Mentis et al., 1998; Jagust, 2000; de la Torre, 2004). AD and cerebrovascular diseases share common risk factors (Stewart et al., 1998; Breteler, 2000; Casserly and Topol, 2004), suggesting similarities in their pathogenic mechanisms. Furthermore, AD patients have increased cerebrovascular atherosclerosis and exhibit white matter abnormalities resembling ischemic lesions (Brun and Englund, 1986; Roher et al., 2003, 2004; Van Dijk et al., 2004). These observations have been complemented by studies in mouse models of $\mathrm{AD}$ demonstrating that $\mathrm{A} \beta$ disrupts the regula-

Received Dec. 21, 2004; revised Jan. 6, 2005; accepted Jan. 8, 2005.

This work was supported by grants from the National Institutes of Health (NIH) (NS38252 and HL18974 to C.I.; AG15453 to G.A.C.). C.I. is the recipient of a Javits Award from NIH-National Institute of Neurological Disorders and Stroke.

Correspondence should be addressed to Dr. C. ladecola, Division of Neurobiology, Weill Medical College of Cornell University, 411 East 69th Street, KB410, New York, NY 10021. E-mail: coi2001@med.cornell.edu.

DOI:10.1523/JNEUROSCI.5207-04.2005

Copyright $\odot 2005$ Society for Neuroscience $\quad$ 0270-6474/05/251769-09\$15.00/0 tion of the cerebral circulation, rendering the brain more susceptible to injury (Zhang et al., 1997). Thus, mice overexpressing APP have a profound attenuation of the increase in CBF produced by neural activity, a critical homeostatic mechanism by which the brain regulates substrate delivery and removes deleterious byproducts of metabolism (Niwa et al., 2000a, 2002b). Furthermore, APP mice have an impairment in cerebrovascular responses mediated by the release of vasoactive factors from brain endothelial cells, such as nitric oxide (NO), which protect the brain by maintaining CBF during hypotension (Huang et al., 1996; Iadecola et al., 1999; Jones et al., 1999; Niwa et al., 2002b). These cerebrovascular alterations are attributable to direct effects of $A \beta$ on cerebral blood vessels and not to neural dysfunction (Niwa et al., 2000b, 2001b).

The mechanisms by which $A \beta$ alters cerebrovascular regulation have not been elucidated. $A \beta$-induced vascular inflammation, activation of scavenger receptors, and upregulation of endothelin-1 have all been implicated (Crawford et al., 1998; Deane et al., 2003; Paris et al., 2003). Central to these mechanisms is increased production of reactive oxygen species (ROS) leading to vascular oxidative stress (Thomas et al., 1996; Niwa et al., 2000b, 2001b; Paris et al., 2003; Park et al., 2004a). However, the link between $\mathrm{A} \beta$ and vascular ROS production has been missing (Stamler, 1996; Iadecola, 2004). A major sources of vascular ROS is NADPH oxidase (Griendling et al., 1994; Mohazzab et al., 1994; Li and Shah, 2004), a multiunit enzyme first described in neutrophils (Babior, 2004; Lambeth, 2004). After activation, the 
membrane-bound subunits, p22 $2^{\text {phox }}$ and the catalytic subunit gp91 ${ }^{\text {phox }}$, assemble with the cytoplasmic subunits $\left(\mathrm{p} 47^{\text {phox }}\right.$, $\mathrm{p} 40^{\text {phox }}, \mathrm{p} 67^{\text {phox }}$, and RAC), leading to transfer of electrons from NADPH to molecular oxygen and production of the ROS superoxide (Lambeth, 2004). Here, we report that NADPH oxidase is responsible for the ROS production mediating the cerebrovascular dysfunction induced by $\mathrm{A} \beta$, an effect attributable in part to a reduction in NO bioavailability.

\section{Materials and Methods}

Mice

All experiments were performed in male mice ranging in age from 2 to 3 months. Breeder pairs of B6.129-Cybb $b^{\text {tmIDin }} /$ J mice lacking the gp 91 phox subunit of NADPH oxidase (gp91 ${ }^{0 / 0}$ ) (Pollock et al., 1995) were purchased from The Jackson Laboratory (Bar Harbor, ME) and maintained by brother (hemizygous for the null allele)-sister (homozygous null) matings (Park et al., 2004b). The Tg2576 transgenic line overexpresses the Swedish mutant (K670N M671I) human $\mathrm{APP}_{695}$ driven by hamster prion protein regulatory sequences (Hsiao et al., 1996). The Tg2576 transgene array was maintained on a mixed B6/SJL background and on the inbred 129 S6 background (Niwa et al., 2000a). PCR was used for genotyping the APP transgene array, as described previously (Niwa et al., 2000a). To produce APP transgenic mice (henceforth designated Tg2576), with or without gp $91^{\text {phox }}$, gp $91^{0 / 0}$ females were crossed with Tg2576 males; because the gene encoding gp91 ${ }^{\text {phox }}(C y b b)$ is on the $\mathrm{X}$ chromosome, male offspring do not express gp91 ${ }^{\text {phox }}$. To produce Tg2576-positive or -negative mice expressing gp91 ${ }^{\text {phox }}, \mathrm{C} 57 \mathrm{BL} / 6 \mathrm{~J} \mathrm{fe}-$ males were crossed with Tg2576 males; only male offspring were used. CBF results did not differ between the offspring of B6/SJL-Tg2576 or 129S6.Tg2576 males. Comparisons were among age-matched animals. gp91 ${ }^{0 / 0}$ mice were back-crossed with C57BL/6J strain six times and genotyped.

\section{General surgical procedures}

All experimental procedures were approved by the Institutional Animal Use and Care Committee. As described in detail previously (Iadecola et al., 1999; Niwa et al., 2001a; Park et al., 2004a), mice were anesthetized with isoflurane (induction, $5 \%$; maintenance, $1-2 \%$ ). One of the femoral arteries was cannulated for recording of arterial pressure and collection of blood samples. Mice were intubated and artificially ventilated with an oxygen-nitrogen mixture adjusted to provide an arterial $\mathrm{pO}_{2}$ of $120-140$ $\mathrm{mmHg}$ (supplemental Table 1, available at www.jneurosci.org as supplemental material). Rectal temperature was maintained at $37^{\circ} \mathrm{C}$ using a thermostatically controlled rectal probe connected to a heating pad. After surgery, isoflurane was gradually discontinued, and anesthesia was maintained with urethane ( $750 \mathrm{mg} / \mathrm{kg}$; i.p.) and $\alpha$-chloralose $(50 \mathrm{mg} / \mathrm{kg}$; i.p.). Throughout the experiment, the level of anesthesia was monitored by testing corneal reflexes and motor responses to tail pinch.

\section{Monitoring of cerebral blood flow}

A small craniotomy $(2 \times 2 \mathrm{~mm})$ was performed to expose the somatosensory cortex, the dura was removed, and the site was superfused with a modified Ringer's solution $\left(37^{\circ} \mathrm{C} ; \mathrm{pH} 7.3-7.4\right)$ (Iadecola et al., 1999). $\mathrm{CBF}$ was continuously monitored at the site of superfusion with a laserDoppler probe (Vasamedic, St. Paul, MN) positioned stereotaxically on the cortical surface and connected to a computerized data acquisition system. CBF values were expressed as percentage increase relative to the resting level. Zero values for CBF were obtained after the heart was stopped by an overdose of isoflurane at the end of the experiment.

\section{Detection of ROS by hydroethidine}

Hydroethidine (HE; dihydroethidium; $2 \mu \mathrm{m}$; Molecular Probes, Eugene, OR) was dissolved in DMSO and further diluted in Ringer's solution to a final DMSO concentration of $<0.5 \%$, which does not affect cerebrovascular responses in this preparation (Niwa et al., 2000a,b). HE was topically superfused on the somatosensory cortex for $60 \mathrm{~min}$ (Park et al., $2004 \mathrm{~b}$ ). At the end of the superfusion, the brain was removed and frozen $\left(-30^{\circ} \mathrm{C}\right)$. Brain sections (thickness, $\left.20 \mu \mathrm{m}\right)$ were cut serially in a cryostat starting from the beginning to the end of the corpus callosum and col- lected at $100 \mu \mathrm{m}$ intervals. This area includes the cortex underlying the cranial window. ROS production was assessed using methods from our laboratory that have been published previously (Park et al., 2004a,b). Briefly, brain sections were examined under an Eclipse E800 fluorescence microscope (Nikon, Melville, NY) equipped with an ethidium filter set (number 31014; Chroma Technology, Brattleboro, VT). Images were acquired with a computer-controlled digital monochrome camera (Coolsnap; Roper Scientific, Trenton, NJ). Image acquisition was performed with the same fluorescence settings in all cases. Ethidium fluorescence was assessed in the brain area superfused with HE. The analysis of ROS production in the different conditions studied (see below, Experimental protocol for CBF experiments) was performed in a blinded manner using IPLab software (Scanalytics, Fairfax, VA). After background subtraction of the camera dark current, pixel intensities of ethidium signals were quantified. Fluorescent intensities of all sections (15-20 per animal) were added, divided by the total number of pixels analyzed, and expressed as relative fluorescence units. To study the role of NADPH oxidase in $\mathrm{A} \beta_{1-40}$-induced ROS production, Ringer's solution containing $\mathrm{HE}$ alone (vehicle), HE plus gp91ds-tat $(1 \mu \mathrm{M})$, or HE plus sgp91dstat $(1 \mu \mathrm{M})$ was superfused for $30 \mathrm{~min}$, followed by coapplication of $\mathrm{A} \beta$ ( 5 $\mu \mathrm{M})$ for 30-40 min. In experiments with $\mathrm{Tg} 2576$ with or without gp91 ${ }^{\text {phox }}$, Ringer's solution containing HE was superfused for $60 \mathrm{~min}$. At the end of superfusion, brains were removed and processed for ROS assessment as described above.

\section{Measurement of $A \beta$}

$\mathrm{A} \beta$ was measured using an ELISA-based assay, as described previously (Scheuner et al., 1996). Briefly, the left hemispheres from the mice used for CBF studies were sonicated in $1 \%$ SDS with protease inhibitors and centrifuged. The supernatant contained SDS-soluble A $\beta$ peptides. The pellet was sonicated in $70 \%$ formic acid and centrifuged as described above. The formic acid extract was neutralized by a 1:20 dilution into $1 \mathrm{M}$ Tris phosphate buffer, $\mathrm{pH}$ 8.0. $\mathrm{A} \beta_{1-40}$ and $\mathrm{A} \beta_{1-42}$ concentrations were determined in supernatant (SDS soluble) and in the formic acid extract of the pellet (SDS insoluble) using the BAN-50/BA-27 and BAN-50/ BC-05 sandwich ELISA as described previously (Scheuner et al., 1996). Concentrations in picomoles per gram of brain tissue were calculated by comparing the sample absorbance with the absorbance of known concentrations of synthetic $\mathrm{A} \beta_{1-40}$ and $\mathrm{A} \beta_{1-42}$.

\section{Experimental protocol for $C B F$ experiments}

$\mathrm{CBF}$ recordings were started after arterial pressure and blood gases were in a steady state (supplemental Table 1, available at www.jneurosci.org as supplemental material). All pharmacological agents studied were dissolved in Ringer's solution unless otherwise indicated.

Effect of topical application of $A \beta_{1-40}$ on functional hyperemia and endothelium-dependent and-independent responses. The cranial window was first superfused with Ringer's solution, and CBF responses to whisker stimulation were recorded. The whiskers were gently stroked for $60 \mathrm{~s}$ with a cotton-tipped applicator. In some mice, the endotheliumdependent vasodilators acetylcholine (ACh; $10 \mu \mathrm{M}$; Sigma), bradykinin (BK; $50 \mu \mathrm{M}$; Sigma), or the calcium ionophore A23187 (3 $\mu \mathrm{m}$; Sigma) were superfused topically for $3-5 \mathrm{~min}$. CBF responses to the NO donor $S$-nitroso-D-penicillamine (SNAP; $50 \mu \mathrm{M}$; Sigma) or to the NOindependent vasodilator adenosine (400 $\mu \mathrm{M}$; Sigma) were also tested (Yang et al., 2003). After testing CBF responses during Ringer's solution superfusion, the superfusion solution was changed to Ringer's solution containing $A \beta_{1-40}(5 \mu \mathrm{M}$; rPeptide, Athens, GA). This concentration of $\mathrm{A} \beta_{1-40}$ was previously found to produce maximal cerebrovascular effects (Niwa et al., 2000a,b, 2001b). As in previous studies (Niwa et al., 2000a,b, 2001b; Park et al., 2004a), to minimize aggregation of the peptide during the experiment, $\mathrm{A} \beta_{1-40}$ was freshly solubilized in DMSO and then diluted in normal Ringer's solution. The final DMSO concentration was $<0.5 \%$. The CBF response to whisker stimulation, ACh, BK, A23187, SNAP, or adenosine was tested $30-40 \mathrm{~min}$ after $\mathrm{A} \beta_{1-40}$ superfusion. This time interval was selected on the basis of previous studies in which the time course of the cerebrovascular effects of $A \beta_{1-40}$ was investigated (Niwa et al., 2000a,b).

Effect of gp91ds-tat. In some experiments, the effects of the NADPH oxi- 

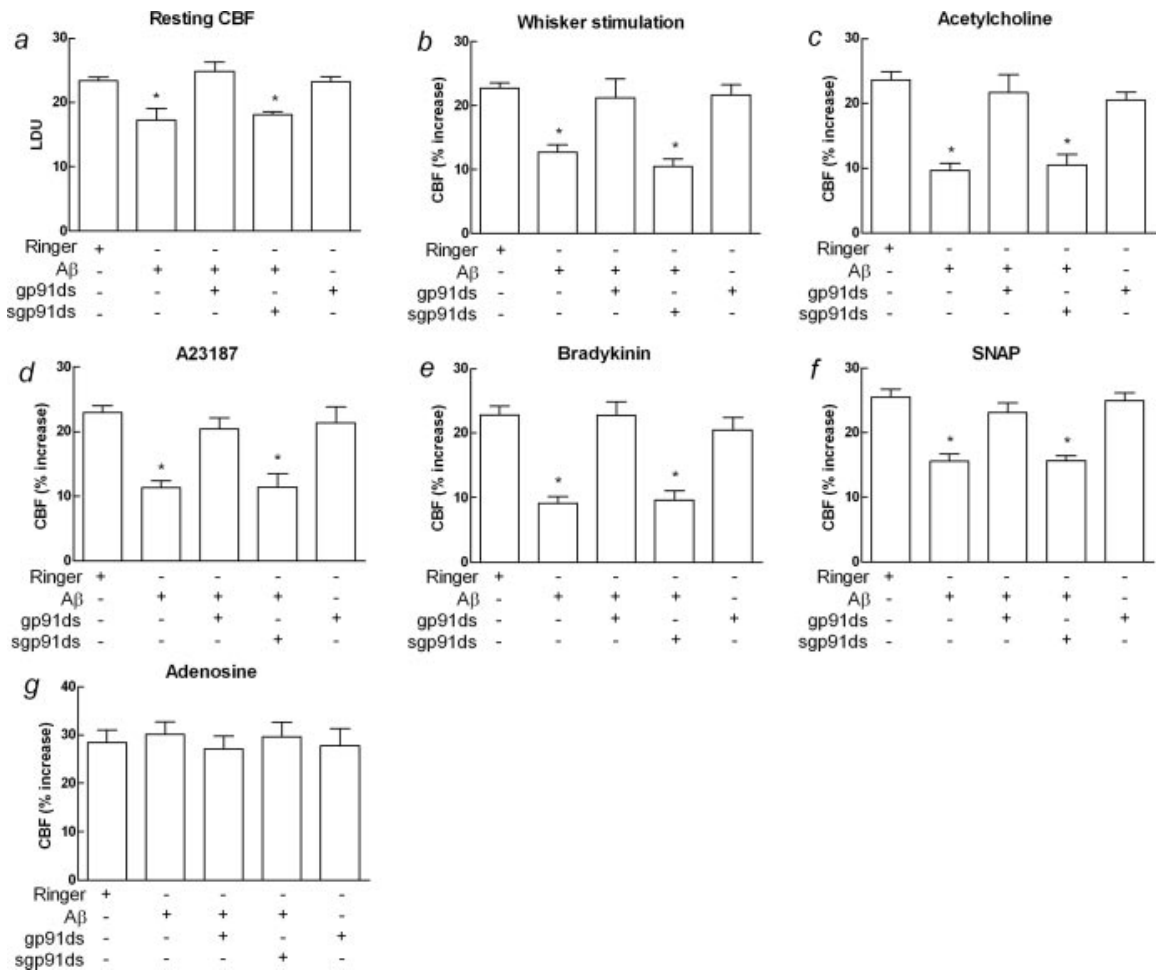

Figure 1. Effect of suffusion of $A \beta_{1-40}(5 \mu \mathrm{m})$ on the mouse somatosensory cortex with or without the NADPH oxidase peptide assembly inhibitor gp91ds-tat (gp91-ds) or its scrambled version (sgp91-ds). A $\beta$ attenuates resting CBF $(\boldsymbol{a})$ and reduces (BF responses to whisker stimulation $(\boldsymbol{b})$, acetylcholine $(\boldsymbol{c})$, the calcium ionophore A23187 (d) , bradykinin $(\boldsymbol{e})$, and the N0 donor SNAP $(\boldsymbol{f}) . \mathrm{A} \beta$ did not alter the vasodilation produced by the $\mathrm{N} 0$-independent vasodilator adenosine $(\boldsymbol{g})$. The cerebrovascular effects of $A \beta$ were abrogated by pretreatment with gp 91 ds-tat but not sgp91-ds. LDU, Laser-Doppler perfusion units. ${ }^{*} p<0.05$; ANOVA and Tukey's test; $n=6$ per group. Error bars represent SEM.
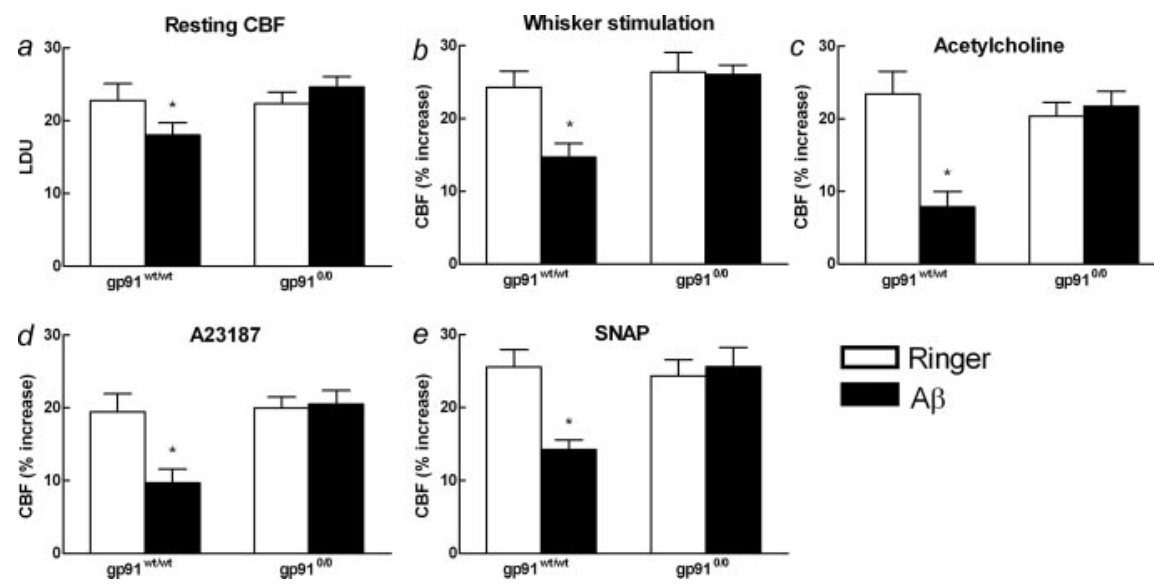

Figure 2. Effect of suffusion of $A \beta_{1-40}(5 \mu \mathrm{m})$ on the somatosensory cortex of wild-type mice and mice lacking $\mathrm{gp} 91^{\text {phox }}$, the catalytic subunit of NADPH oxidase. In gp91 ${ }^{\mathrm{wt} / \mathrm{wt}}, \mathrm{A} \beta_{1-40}$ reduced resting $\mathrm{CBF}(\boldsymbol{a})$ and attenuated the increase in CBF elicited by whisker stimulation (b), acetylcholine (c), A23187 (d), and SNAP (e). A $\beta_{1-40}$ was devoid of cerebrovascular effects in $\mathrm{gp} 91^{0 / 0} . \mathrm{LDU}$, Laser-Doppler perfusion units. ${ }^{*} p<0.05$; ANOVA and Tukey's test; $n=6$ per group. Error bars represent SEM.

dase peptide inhibitor gp9lds-tat (YGRKKRRQRRRCSTRIRRQL-NH ${ }_{2}$ ) (Rey et al., 2001) on the cerebrovascular alterations induced by $\mathrm{A} \beta$ were studied. The scrambled sequence (sgp91ds-tat) (YGRKKRRQRRRCLRITRQSR- $\mathrm{NH}_{2}$ ) served as control. To facilitate entry into cells, the gp91 ${ }^{\text {phox }}$ sequence is linked to the human immunodeficiency virus-tat peptide, an amino acid sequence that is internalized by all cells. The peptides were synthesized (Bio-Synthesis, Lewisville, TX) with or without a fluorescent tag (carboxytetramethylrhodamine). Cerebrovascular effects were as- sessed 40 min after gp91ds-tat $(1 \mu \mathrm{M})$ or sgp91dstat $(1 \mu \mathrm{M})$ superfusion. After the experiment, the brain was removed and frozen, and the area under the window was sectioned in a cryostat (thickness, $20 \mu \mathrm{m}$ ). The penetration of the peptide in the cortex underlying the cranial window was verified in all cases by using a fluorescence microscope. In experiments using HE, peptides without a fluorescent tag were used.

Cerebrovascular reactivity in $\mathrm{Tg} 2576, \mathrm{gp} 91^{0 / 0}$, and crosses between $\mathrm{Tg} 2576$ and $g p 91^{0 / 0}$. In these studies, CBF responses to whisker stimulation, ACh, BK, A23187, SNAP, and adenosine were tested in Tg2576. Transgene negative littermates served as controls. CBF responses were also examined in crosses between $\operatorname{Tg} 2576$ and gp $91^{0 / 0}$. Four groups of mice were studied: transgene-negative mice with wild-type gp91 ${ }^{\text {hox }}\left(\mathrm{gp} 91^{\mathrm{wt} / \mathrm{wt}}\right), \mathrm{Tg} 2576$ mice with wildtype gp91 ${ }^{\text {phox }}\left(\operatorname{Tg} 2576 / \mathrm{gp} 91^{\mathrm{wt} / \mathrm{wt}}\right), \quad \operatorname{Tg} 2576$ mice lacking gp91 phox $\left(\mathrm{Tg} 2576 / \mathrm{gp} 91^{0 / 0}\right)$, and transgene-negative mice lacking gp91 ${ }^{\text {phox }}$ $\left(\mathrm{gp} 91^{0 / 0}\right)$.

Effects of neuronal NO synthase inhibitors on the cerebrovascular effects of $A \beta_{1-40}$. CBF responses to whisker stimulation, ACh, or adenosine were first obtained during Ringer's solution superfusion. Next, the relatively selective neuronal NO synthase (NOS) inhibitor 7-nitroindazole (7-NI; 50 mg/kg; Sigma) (Yang et al., 1999) was administered intraperitoneally, and cerebrovascular responses were tested again 30-40 min later. After 7-NI, A $\beta_{1-40}$ (5 $\mu \mathrm{M})$ was superfused on the neocortex, and responses were tested again 30-40 min later. In experiments in which the $\mathrm{CBF}$ response to whisker stimulation was tested, the $\mathrm{Na}^{+}$channel inhibitor tetrodotoxin (TTX; $3 \mu \mathrm{m}$; Sigma) was superfused after pretreatment of 7-NI or the nonselective NOS inhibitor $N \omega$-nitro-L-arginine (L-NNA; 1 mM; Sigma).

Effects of NOS inhibitors on cerebrovascular responses in $\mathrm{Tg} 2576$. CBF responses to whisker stimulation, $\mathrm{ACh}$, or adenosine were first obtained during Ringer's solution superfusion. Next, the relatively selective neuronal NOS inhibitor 7-NI (50 mg/kg) (Yang et al., 1999) was administered intraperitoneally, and cerebrovascular responses were tested again 30-40 min later. In some experiments, the nonselective NOS inhibitor L-NNA (1 mM; topical superfusion) (Iadecola, 1992) was used instead of 7-NI. In experiments in which the CBF response to whisker stimulation was tested, the $\mathrm{Na}^{+}$channel inhibitor TTX $(3 \mu \mathrm{M})$ was superfused after pretreatment of L-NNA or 7-NI.

\section{Data analysis}

Data are expressed as means \pm SEM. Twogroup comparisons were analyzed by the twotailed $t$ test for dependent or independent samples, as appropriate. Multiple comparisons were evaluated by ANOVA and Tukey's tests. Statistical significance was considered for $p<0.05$.

\section{Results}

The NADPH oxidase assembly inhibitor gp91ds-tat abrogates the cerebrovascular effects of $A \boldsymbol{\beta}$

We used gp91ds-tat, a peptide that prevents the binding of $\mathrm{p} 47^{\text {phox }}$ to gp $91^{\text {phox }}$ and blocks enzyme assembly and activation 
(Rey et al., 2001), to investigate whether NADPH oxidase is responsible for the alteration in cerebrovascular regulation produced by $\mathrm{A} \beta$. Direct application of $\mathrm{A} \beta_{1-40}$ onto the mouse somatosensory cortex reduced baseline $\mathrm{CBF}$ and attenuated the increase in CBF evoked by whisker stimulation (Fig. $1 a, b$ ). In addition, $\mathrm{A} \beta_{1-40}$ attenuated the increase in flow produced by $\mathrm{ACh}, \mathrm{BK}$, and the calcium ionophore A23187 (Fig. 1c-e), agents that act by releasing $\mathrm{NO}$ and other vasoactive factors from cerebral endothelial cells (Sobey and Faraci, 1997; Niwa et al., 2001a). The response to the NO donor SNAP was also attenuated (Fig. 1f), whereas the increase in $\mathrm{CBF}$ produced by adenosine, a response not mediated by NO (Yang et al., 2003), was not affected (Fig. 1g). Superfusion with gp91ds-tat, but not its scrambled version, completely abolished the cerebrovascular effects of $\mathrm{A} \beta_{1-40}$ (Fig. $1 a-f$ ). These data implicate NADPH oxidase in the cerebrovascular dysfunction induced by $\mathrm{A} \beta_{1-40}$.

\section{$\mathrm{A} \boldsymbol{\beta}$ does not impair cerebrovascular regulation in mice lacking the NADPH oxidase subunit gp91 ${ }^{\text {phox }}$}

To provide additional evidence implicating NADPH oxidase in the cerebrovascular dysfunction induced by $\mathrm{A} \beta_{1-40}$, we investigated the effect of $A \beta_{1-40}$ in gp91 $0 / 0$ (Pollock et al., 1995). CBF responses to functional activation, ACh, A23187, and SNAP were normal in gp91 ${ }^{0 / 0}$ (Fig. $2 a-e$ ). However, in gp91 ${ }^{0 / 0}, \mathrm{~A} \beta_{1-40}$ did not alter resting $\mathrm{CBF}$ and the increase in $\mathrm{CBF}$ produced by functional hyperemia or by endothelium-dependent (ACh, A23187) and -independent (SNAP, adenosine) vasodilators (Fig. $2 a-e$ ). These findings provide additional support to the hypothesis that a gp91 ${ }^{\text {phox }}$ containing NADPH oxidase is responsible for the cerebrovascular effects of $\mathrm{A} \beta_{1-40}$.

\section{Tg2576 mice lacking gp91 ${ }^{\text {phox }}$ have normal cerebrovascular reactivity}

In the experiments described above, relatively high concentrations of exogenous $A \beta_{1-40}$ were applied acutely to the neocortex. We next examined whether NADPH oxidase also plays a role in the cerebrovascular dysfunction induced by chronic elevations in endogenous $\mathrm{A} \beta$ comparable with those observed in $\mathrm{AD}$. In these studies, we used Tg2576 in the presence or absence of gp91 ${ }^{\text {phox }}$. $\operatorname{Tg} 2576$ were used at an age at which $\mathrm{A} \beta$ concentrations are beginning to increase as a result of aggregate formation, but before $\mathrm{A} \beta$ deposition in amyloid plaques is observed (Hsiao et al., 1996; Kawarabayashi et al., 2001; Park et al., 2004a). CBF responses to whisker stimulation, ACh, A23187, BK, and SNAP were attenuated in Tg2576 expressing gp91 ${ }^{\text {phox }}$ (Fig. 3a-e). However, cerebrovascular responses were normal in Tg2576 lacking gp91 ${ }^{\text {phox }}$ (Fig. 3a-e), implicating NADPH oxidase in the mechanism of the vascular dysfunction induced by $\mathrm{A} \beta$. To rule out that the lack of
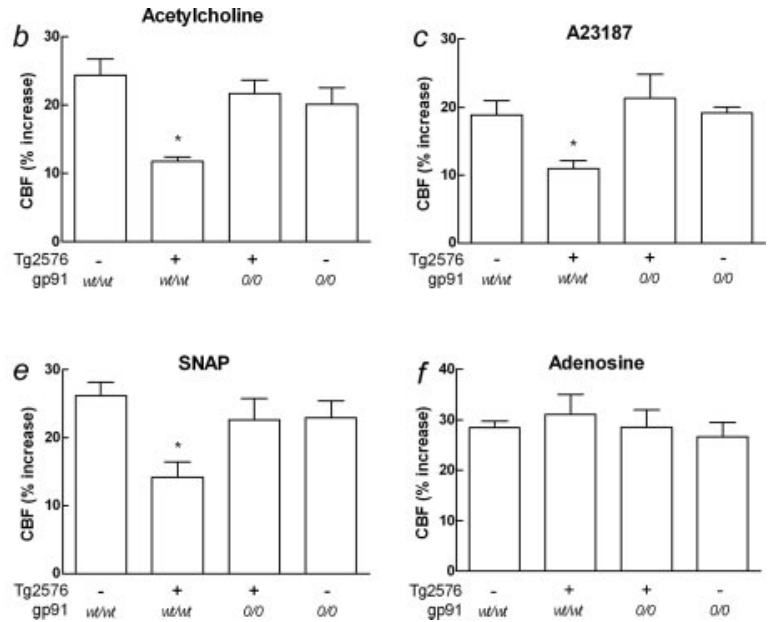

Figure 3. Cerebrovascular function in crosses between $\operatorname{Tg} 2576$ and $\mathrm{gp} 91^{0 / 0}$. Four groups of mice were studied: mice without the transgene and carrying wild-type gp91 ${ }^{\text {phox }}$, mice carrying Tg2576 and wild-type for gp91 ${ }^{\text {phox }}$, mice carrying the transgene , and mice without the transgene and lacking gp91 ${ }^{\text {hhox }} \cdot \operatorname{Tg} 2576 / \mathrm{gp} 91^{\text {wt/wt }}$ mice exhibited attenuation of the increase in CBF produced by whisker stimulation $(\boldsymbol{a})$, acetylcholine $(\boldsymbol{b}), \mathrm{A} 23187(\boldsymbol{c})$, bradykinin $(\boldsymbol{d})$, and the N0 donor SNAP $(\boldsymbol{e})$. The gp91 ${ }^{0 / 0}$ mice had normal cerebrovascular reactivity $(\boldsymbol{a}-\boldsymbol{f}) .{ }^{*} p<0.05$; ANOVA and Tukey's test; $n=6$ per group. Error bars
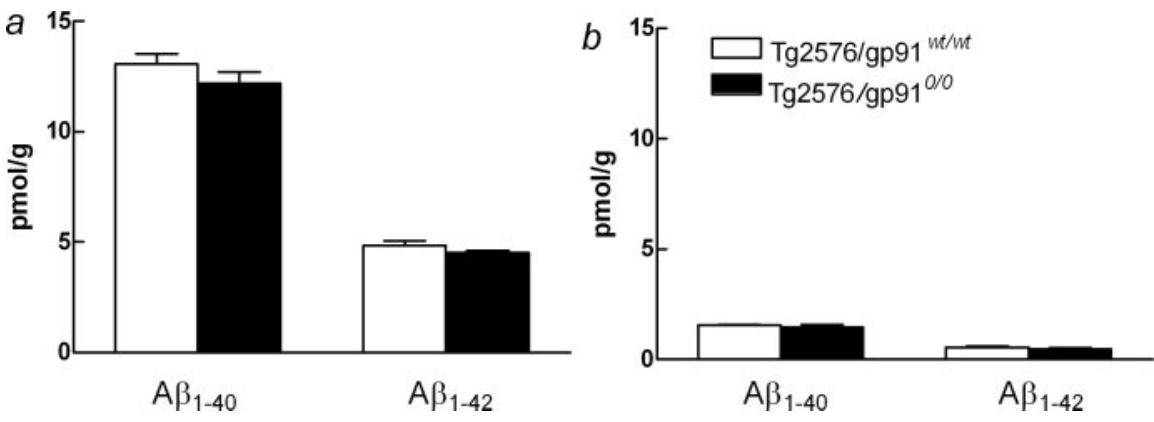

Figure 4. Brain levels of $A \beta_{1-40}$ and $A \beta_{1-42}$ in Tg2576 with (Tg2576/gp91 ${ }^{\text {wt/wt }}$ ) and without $\left(\operatorname{Tg} 2576 / g p 91^{0 / 0}\right)$ gp $91^{\text {phox }}$. Both SDS-soluble $(\boldsymbol{a})$ and SDS-insoluble $(\boldsymbol{b}) \mathrm{A} \beta$ were examined. $n=6$ per group. Error bars represent SEM.

gp91 ${ }^{\text {phox }}$ affected APP processing and $\mathrm{A} \beta$ production, $\mathrm{A} \beta$ levels were measured in Tg2576 carrying wild-type gp91 ${ }^{\text {phox }}$ or lacking gp91 ${ }^{\text {phox }}$. As illustrated in Figure 4, levels of both SDS-soluble and SDS-insoluble forms of $\mathrm{A} \beta_{1-40}$ and $\mathrm{A} \beta_{1-42}$ did not differ between Tg2576 carrying wild-type gp91 ${ }^{\text {phox }}$ or lacking gp91 ${ }^{\text {phox }}$. Therefore, the absence of cerebrovascular alterations in Tg2576 lacking gp91 ${ }^{\text {phox }}$ cannot be attributed to reduced levels of $\mathrm{A} \beta$.

gp91 ${ }^{\text {phox }}$ is required for $A \boldsymbol{\beta}$-induced free radical production

The studies presented above suggest that a gp91 ${ }^{\text {phox }}$-containing NADPH oxidase is involved in the cerebrovascular alterations induced by $\mathrm{A} \beta_{1-40}$. To determine whether NADPH oxidase is the source of the ROS underlying the cerebrovascular dysfunction, we investigated ROS production using hydroethidine fluoromicrography (Park et al., 2004a,b). In wild-type mice, neocortical application of $\mathrm{A} \beta_{1-40}$ increased ROS production (Fig. 5a,b,h). Similarly, ROS production was elevated in the neocortex of Tg2576 (Fig. 5g,h). A $\beta_{1-40}$-induced ROS-production was blocked by the peptide inhibitor gp91ds-tat (Fig. $5 d, h$ ) but not by its scrambled version (Fig. 5e,h) and was not elevated in Tg2576 lacking gp91 ${ }^{\text {phox }}$ (Fig. 5f,h). These findings demonstrate that a gp91 ${ }^{\text {phox }}$-containing NADPH oxidase is the source of the ROS induced by $\mathrm{A} \beta_{1-40}$. 

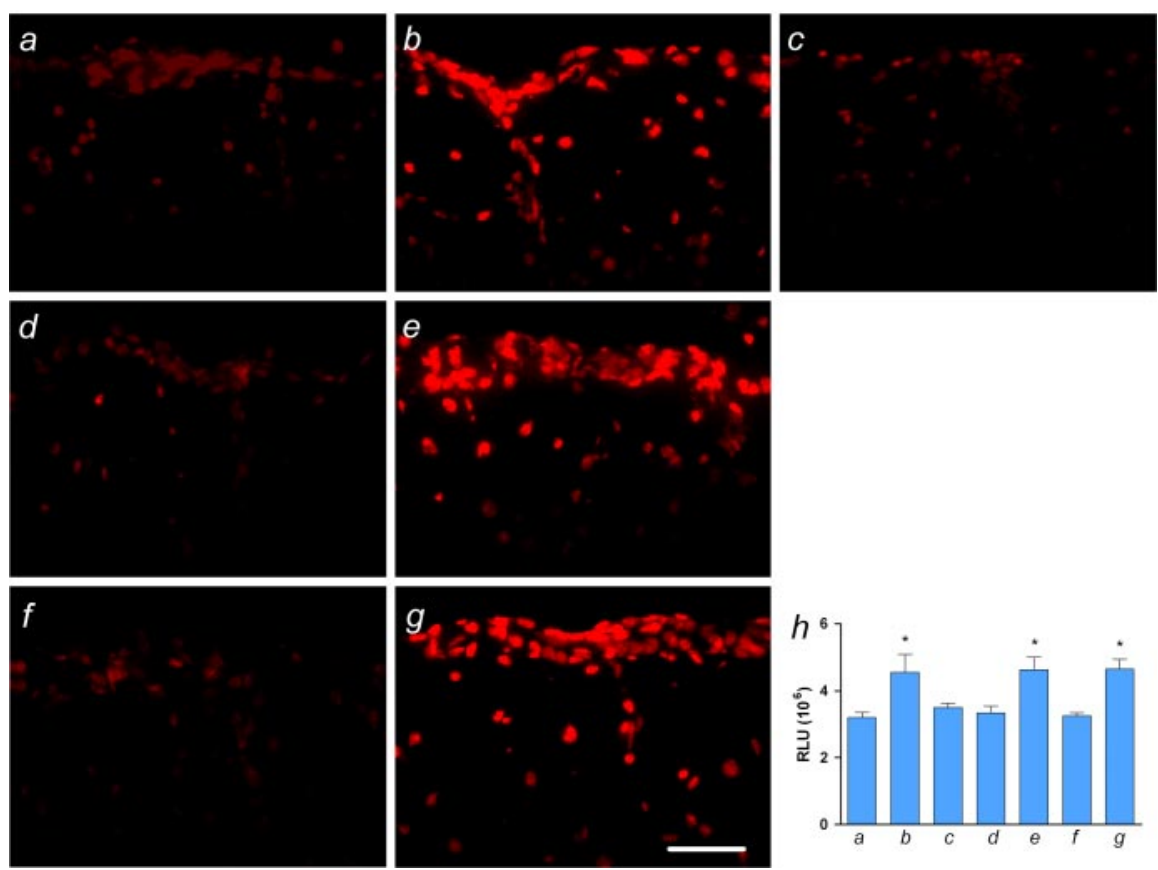

Figure 5. ROS production in somatosensory cortex assessed by hydroethidine microfluorography. $A \beta_{1-40}$ neocortical superfusion $(5 \mu \mathrm{m})$ increases ROS production in wild-type mice $(\boldsymbol{a}, \boldsymbol{b})$ but not in mice lacking gp91 ${ }^{\text {phox }}(\boldsymbol{a}, \boldsymbol{c})$. The increase in ROS production produced by $A \beta$ is blocked by the NADPH oxidase assembly inhibitor gp91ds-tat (gp91ds) (d) but not by its scrambled version (sgp91-ds) (e). ROS overproduction is present in $\operatorname{Tg} 2576$ with wild-type gp91 ${ }^{\text {phox }}(\boldsymbol{g})$ but not in $\operatorname{Tg} 2576$ lacking gp91 ${ }^{\text {phox }}$ $(\boldsymbol{f})$. The bar graphs in $\boldsymbol{h}$ represent group data corresponding to $\boldsymbol{a}-\boldsymbol{g}$. Scale bar, $50 \mu \mathrm{m}$. RLU, Relative fluorescent light units. ${ }^{*} p<$ 0.05; ANOVA and Tukey's test; $n=6$ per group. Error bars represent SEM.

\section{A $\beta$ does not disrupt functional hyperemia if NO synthesis} is inhibited

We then sought to examine the mechanisms by which $\mathrm{A} \beta$ derived ROS attenuate cerebrovascular responses. One possibil-
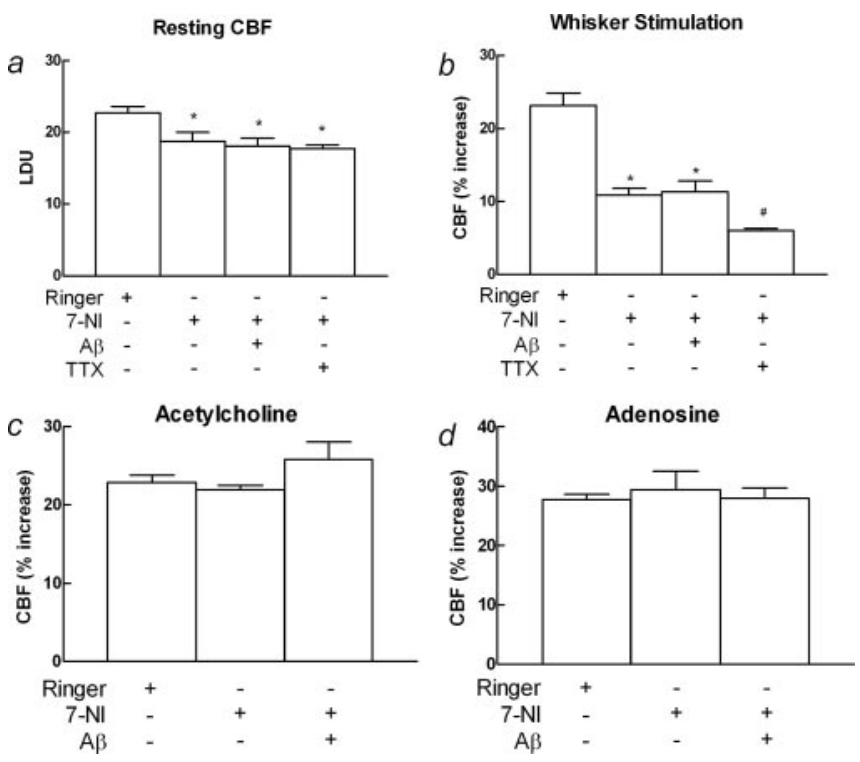

Figure 6. Effect of NOS inhibition on the cerebrovascular actions of $A \beta$ peptides. The neuronal NOS inhibitor 7-NI attenuated resting $\mathrm{CBF}(\boldsymbol{a})$ and the CBF response to whisker stimulation (b) but not acetylcholine or adenosine $(\boldsymbol{c}, \boldsymbol{d})$. Application of $A \beta_{1-40}$ after 7-NI did not further reduce resting $\mathrm{CBF}(\boldsymbol{a})$ or the responses to whisker stimulation $(\boldsymbol{b})$. The absence of $A \beta_{1-40}$ effects could not be attributed to the fact that the response was already maximally attenuated, because the $\mathrm{Na}^{+}$channel blocker TTX further attenuated the CBF response to whisker stimulation $(\boldsymbol{b})$. LDU, Laser-Doppler perfusion units. ${ }^{*} p<0.05$ from Ringer's solution; ${ }^{\#} p<0.05$ from 7-Nl; ANOVA and Tukey's test; $n=6$ per group. Error bars represent SEM. ity is that ROS inactivate $\mathrm{NO}$ and reduce its bioavailability (Beckman et al., 1990; Droge, 2002). This possibility is suggested by our observation that responses to the NO donor SNAP are attenuated by exogenous $\mathrm{A} \beta_{1-40}$ (Figs. $1 f, 2 e$ ) and in Tg2576 (Fig. 3e). We reasoned that if the vascular dysfunction is related to scavenging of $\mathrm{NO}$ by free radicals, inhibition of NO synthesis would prevent the effect of $A \beta_{1-40}$. The neuronal NOS inhibitor 7-NI attenuated resting $\mathrm{CBF}$ and the $\mathrm{CBF}$ increase produced by whisker stimulation, but not ACh, a response mediated by endothelial NOS (Fig. $6 a-c$ ). After 7-NI, A $\beta_{1-40}$ superfusion failed to attenuate resting $\mathrm{CBF}$ and the response to whisker stimulation (Fig. $6 a, b)$. Furthermore, in Tg2576, 7-NI did not alter resting $\mathrm{CBF}$ or the increase in CBF produced by whisker stimulation (Fig. 7a,b). Similar results were obtained with the nonselective NOS inhibitor L-NNA. To exclude that the lack of attenuation in $\operatorname{Tg} 2576$ was attributable to the fact that the response was maximally reduced and could not be attenuated further, we used TTX, a Na ${ }^{+}$channel blocker that attenuates functional hyperemia by inhibiting neural activity (Yang et al., 1999). As illustrated in Figures $6 b$ and $7 b$, application of TTX after 7-NI attenuated the response to whisker stimulation further, attesting to the fact that the CBF response was not maximally reduced. These findings indicate that NO scavenging by ROS contributes to the attenuation in functional hyperemia and $\mathrm{ACh}$ responses induced by $\mathrm{A} \beta_{1-40}$.

\section{Discussion}

We found that NADPH oxidase is a key factor in the cerebrovascular dysfunction induced by $\mathrm{A} \beta_{1-40}$. First, the NADPH oxidase assembly inhibitor gp91ds-tat prevented the ROS production induced by exogenous $A \beta_{1-40}$ and abrogated the associated alteration in functional hyperemia and endothelium-dependent relaxation. Second, exogenous $\mathrm{A} \beta_{1-40}$ did not elicit ROS production and vascular dysregulation in mice lacking the essential subunit of NADPH oxidase gp91 ${ }^{\text {phox }}$. Third, the increase in ROS production and the related vascular dysregulation observed in Tg2576 was not observed in Tg2576 lacking gp91 ${ }^{\text {phox }}$. The genetic background of the mice was carefully matched to eliminate confounding effects related to background genes. These findings provide the first demonstration that a gp91 ${ }^{\text {phox }}$ containing NADPH oxidase is the link between $\mathrm{A} \beta_{1-40}$ and the ROS mediating the vascular dysregulation.

We then examined the potential mechanisms by which ROS alter the regulation of the cerebral circulation. In particular, we investigated whether $\mathrm{A} \beta_{1-40}$-induced ROS inactivate the potent vasodilator NO. NO has emerged as a major factor in the mechanisms regulating the cerebral circulation (Iadecola and Niwa, 2002). NO contributes to the increase in CBF produced by neural activity, a critical homeostatic mechanism that matches energy consumption to delivery of substrates through blood flow (Iadecola, 2004). Furthermore, NO released from endothelial cells plays a critical role in the compensatory response of cerebral 
blood vessels to hypotension (Jones et al., 1999; Busse and Fleming, 2003) and to vasoactive agents such as ACh (Ayata et al., 1996; Sobey and Faraci, 1997). We found that $\mathrm{A} \beta_{1-40}$ attenuates the increase in $\mathrm{CBF}$ produced by the NO donor SNAP, an effect abolished by blocking NADPH oxidase-dependent ROS production. This observation supports the hypothesis that NO scavenging by ROS is involved in the attenuation in NO-dependent responses induced by $\mathrm{A} \beta_{1-40}$. To provide additional evidence for this hypothesis, we assessed the effects of $\mathrm{A} \beta_{1-40}$ after inhibition of $\mathrm{NO}$ synthesis. We found that $A \beta_{1-40}$ failed to attenuate the responses after administration of NOS inhibitors. These findings implicate $\mathrm{NO}$ as a target for the effects of NADPH oxidase-derived radicals. The vasodilatatory action of NO is potently antagonized by ROS, a process that is thought to be mediated by multiple mechanisms (Soriano et al., 2001; Droge, 2002; Adachi et al., 2004; Iadecola, 2004). NO reacts with the ROS superoxide to form peroxynitrite, a reaction that reduces the amount of $\mathrm{NO}$ available for vasodilation (Beckman et al., 1990; Adachi et al., 2004). During functional hyperemia, NO produced by neuronal NOS diffuses to local arterioles to mediate vasodilation (Ayata et al., 1996; Yang and Iadecola, 1997). The present findings, in concert with previous data demonstrating the peroxynitrite marker 3-nitrotyrosine in cerebral arterioles of Tg2576 (Park et al., 2004a), suggest that once NO reaches the blood vessels, it reacts with superoxide to form peroxynitrite. In the case of the response to $\mathrm{ACh}, \mathrm{NO}$ produced in endothelial cells reacts with locally generated superoxide to form peroxynitrite, resulting in impairment of vasodilation. Peroxynitrite also leads to the nitration of other protein involved in vascular regulation. These include the enzyme prostacyclin synthase, which produces the vasodilator prostacyclin, and the free-radical scavenging enzyme superoxide dismutase (Zou et al., 1999; Guo et al., 2003; Ischiropoulos and Beckman, 2003). Furthermore, ROS inactivate the essential NOS cofactor tetrahydrobiopterin and attenuate NO production (Katusic, 2001). Therefore, the disturbance in the vasodilation may results both from the loss of $\mathrm{NO}$ and from oxidative/nitrosative stress of vascular proteins. These alterations, collectively, produce vascular dysregulation by increasing oxidative stress and producing vasoconstriction of cerebral vessels. However, the CBF responses evoked by BK and A23187 are not dependent on NO (Rosenblum, 1987; Rosenblum et al., 1989; Niwa et al., 2001a). This finding suggests that the mechanisms of the cerebrovascular dysfunction exerted by $\mathrm{A} \beta_{1-40}$ involve factors other than NO scavenging and that other effects of ROS on proteins involved in vascular function are also likely to play a role (Droge, 2002).

Although there are several enzymatic systems that can produce ROS (Droge, 2002), the enzyme NADPH oxidase has emerged as a major source of ROS in several cell types (Babior, 2004; Lambeth, 2004). In blood vessels, NADPH oxidase is re-
Resting CBF

Whisker Stimulation

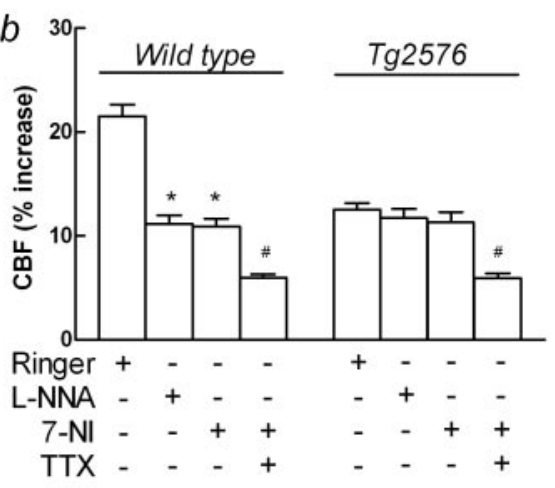

Adenosine

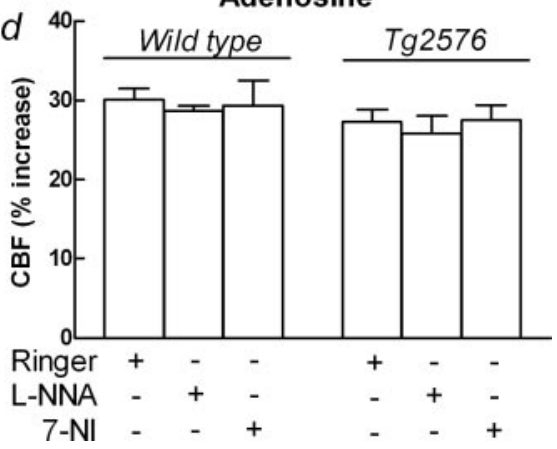

Figure 7. Effect of NOS inhibition on the cerebrovascular actions of APP overexpression. In wild-type mice, the nonselective NOS inhibitor L-NNA attenuated resting CBF $(\boldsymbol{a})$ and the CBF response to whisker stimulation $(\boldsymbol{b})$ or acetylcholine $(\boldsymbol{c})$. The CBF ce produced by adenosine was not affected $(\boldsymbol{d})$. The neuronal NOS inhibitor 7-Nl attenuated resting CBF and the CBF response

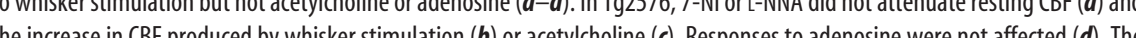
significance of this finding is unclear. LDU, Laser-Doppler perfusion units ${ }^{*} p<0.05$ from Ringer's solution in wild-type mice; ${ }^{\#} p<0.05$ from 7-NI in wild-type and Tg2576 mice; ${ }^{~} p<0.05$ from Ringer's solution in Tg2576 mice; ANOVA and Tukey's test; $n=6$ per group. Error bars represent SEM.

sponsible for the ROS production and vascular dysfunction in a wide variety of vascular pathologies, including angiotensininduced hypertension, hyperlipidemia, atherosclerosis, and hyperhomocysteinemia (Faraci, 2003; Li and Shah, 2004). Although the enzyme is also present in neurons and glia both in the normal brain and in AD (Bianca et al., 1999; Shimohama et al., 2000; Abramov et al., 2004), it is likely that the effects of $A \beta_{1-40}$ are mediated by vascular NADPH oxidase. ROS are highly reactive chemical species that do not travel long distances (Stamler, 1996). Therefore, the ROS responsible for the vascular effects of $A \beta_{1-40}$ are most likely generated at the vascular level. Furthermore, oxidative stress is observed in cerebral vessels of Tg2576 at a time when there is no evidence of oxidative stress in other brain cells or presence of amyloid plaques (Park et al., 2004a). This observation suggests that vascular oxidative stress is an early event in the brain dysfunction associated with $\mathrm{A} \beta$ overproduction in mouse. Vascular dysfunction is proportional to the amount of $A \beta_{1-40}$ and occurs even in mice whose $A \beta$ level does not change with age and never develop plaques (Iadecola et al., 1999; Niwa et al., 2000a). Therefore, it is likely that soluble $\mathrm{A} \beta$ monomers or small oligomers are the active entity. Future studies in which the cellular source of the ROS is established would help define the vascular and nonvascular components of the oxidative stress.

The mechanisms by which $\mathrm{A} \beta_{1-40}$ activates NADPH oxidase remain to be defined. One possibility is that $\mathrm{A} \beta$ activates NADPH 
oxidase through the scavenger receptors RAGE (receptor for advanced glycation end product) or CD36 (El Khoury et al., 1996, 2003; Yan et al., 1996; Coraci et al., 2002). Activation of these receptors leads to increased ROS production, which is mediated by NADPH oxidase (Wautier et al., 2001; Bamberger et al., 2003; Abramov et al., 2004; Fuhrman et al., 2004). Indeed, evidence of activation of NADPH oxidase by $\mathrm{A} \beta$ has been provided in microglial and astrocytic cultures and in AD brains (Bianca et al., 1999; Shimohama et al., 2000; Parvathenani et al., 2003). Another possibility is that the NADPH activation occurs through endothelin receptors. $A \beta$ upregulates endothelin-1 in cerebral blood vessels (Deane et al., 2003), and activation of endothelin receptors leads to production of ROS through NADPH oxidase (Duerrschmidt et al., 2000; Zheng et al., 2003). It is, therefore, conceivable that $\mathrm{A} \beta$ leads to activation of NADPH oxidase through endothelin receptors. Regardless of the mechanisms of activation, the findings provide evidence that NADPH oxidase is the missing link between $\mathrm{A} \beta$ and the oxidative stress leading to cerebrovascular dysfunction.

What are the implications of $A \beta$-induced vascular dysfunction for $\mathrm{AD}$ ? Reduction in resting $\mathrm{CBF}$ of a magnitude similar to that reported in Tg2576 (Niwa et al., 2002a) and in AD (Jagust, 2000) are not sufficient to produce ischemic cell dysfunction or death (Hossmann, 1994). However, such reductions in CBF can attenuate protein synthesis (Mies et al., 1991), a process that is essential for learning and memory (Martin et al., 2000; Milekic and Alberini, 2002). Furthermore, the impairment of the increase in $\mathrm{CBF}$ evoked by brain activation produces an imbalance between substrate delivery through CBF and energy requirements which, if protracted in time, may deprive the brain of energy substrates and lead to brain dysfunction (Farkas et al., 2002). Another deleterious vascular effect of $\mathrm{A} \beta_{1-40}$ is a disruption of cerebrovascular autoregulation (Niwa et al., 2002b), a mechanism in part mediated by vasoactive factors produced in endothelial cells, which prevents fall of CBF during hypotension (Huang et al., 1996; Jones et al., 1999; Chillon and Baumbach, 2002). Failure of autoregulation leads to ischemic damage of cortical white matter (Matsushita et al., 1994), a finding that may be responsible for the white matter lesions observed in patients with AD (Brun and Englund, 1986; Van Dijk et al., 2004). These observations, collectively, suggest that $\mathrm{A} \beta$ peptides, in addition to their well known deleterious effects on neurons (Selkoe and Schenk, 2003), can also disrupt the function of cerebral blood vessels. Because $\operatorname{Tg} 2576$ recapitulates the pathobiology of $A \beta$ peptides overproduction in humans, the findings suggest that the alterations in $\mathrm{CBF}$ induced by $\mathrm{A} \beta_{1-40}$ are an early event in the mechanisms of the diseases that precede the deleterious effects resulting from direct actions of $A \beta$ peptides on neurons. Such cerebrovascular dysfunction increases the vulnerability of the brain and is likely to contribute to the mechanisms of AD.

\section{References}

Abramov AY, Canevari L, Duchen MR (2004) $\beta$-Amyloid peptides induce mitochondrial dysfunction and oxidative stress in astrocytes and death of neurons through activation of NADPH oxidase. J Neurosci 24:565-575.

Adachi T, Weisbrod RM, Pimentel DR, Ying J, Sharov VS, Schoneich C, Cohen RA (2004) S-Glutathiolation by peroxynitrite activates SERCA during arterial relaxation by nitric oxide. Nat Med 10:1200-1207.

Ayata C, Ma J, Meng W, Huang P, Moskowitz MA (1996) L-NA-sensitive rCBF augmentation during vibrissal stimulation in type III nitric oxide synthase mutant mice. J Cereb Blood Flow Metab 16:539-541.

Babior BM (2004) NADPH oxidase. Curr Opin Immunol 16:42-47.

Bamberger ME, Harris ME, McDonald DR, Husemann J, Landreth GE (2003) A cell surface receptor complex for fibrillar $\beta$-amyloid mediates microglial activation. J Neurosci 23:2665-2674.
Beckman JS, Beckman TW, Chen J, Marshall PA, Freeman BA (1990) Apparent hydroxyl radical production by peroxynitrite: implications for endothelial injury from nitric oxide and superoxide. Proc Natl Acad Sci USA 87:1620-1624.

Bianca VD, Dusi S, Bianchini E, Dal Pra I, Rossi F (1999) Beta-amyloid activates the $\mathrm{O}-2$ forming NADPH oxidase in microglia, monocytes, and neutrophils. A possible inflammatory mechanism of neuronal damage in Alzheimer's disease. J Biol Chem 274:15493-15499.

Breteler MM (2000) Vascular risk factors for Alzheimer's disease: an epidemiologic perspective. Neurobiol Aging 21:153-160.

Brun A, Englund E (1986) A white matter disorder in dementia of the Alzheimer type: a pathoanatomical study. Ann Neurol 19:253-262.

Busse R, Fleming I (2003) Regulation of endothelium-derived vasoactive autacoid production by hemodynamic forces. Trends Pharmacol Sci 24:24-29.

Casserly I, Topol E (2004) Convergence of atherosclerosis and Alzheimer's disease: inflammation, cholesterol, and misfolded proteins. Lancet 363:1139-1146.

Chillon JM, Baumbach GL (2002) Autoregulation: arterial and intracranial pressure. In: Cerebral blood flow and metabolism (Edvinsson L, Krause DN, eds), pp 395-412. Philadelphia: Lippincott Williams and Wilkins.

Coraci IS, Husemann J, Berman JW, Hulette C, Dufour JH, Campanella GK, Luster AD, Silverstein SC, El-Khoury JB (2002) CD36, a class B scavenger receptor, is expressed on microglia in Alzheimer's disease brains and can mediate production of reactive oxygen species in response to betaamyloid fibrils. Am J Pathol 160:101-112.

Crawford F, Suo Z, Fang C, Mullan M (1998) Characteristics of the in vitro vasoactivity of beta-amyloid peptides. Exp Neurol 150:159-168.

Deane R, Du Yan S, Submamaryan RK, LaRue B, Jovanovic S, Hogg E, Welch D, Manness L, Lin C, Yu J, Zhu H, Ghiso J, Frangione B, Stern A, Schmidt AM, Armstrong DL, Arnold B, Liliensiek B, Nawroth P, Hofman F, et al. (2003) RAGE mediates amyloid-beta peptide transport across the bloodbrain barrier and accumulation in brain. Nat Med 9:907-913.

de la Torre JC (2004) Is Alzheimer's disease a neurodegenerative or a vascular disorder? Data, dogma, and dialectics. Lancet Neurol 3:184-190.

Droge W (2002) Free radicals in the physiological control of cell function. Physiol Rev 82:47-95.

Duerrschmidt N, Wippich N, Goettsch W, Broemme HJ, Morawietz H (2000) Endothelin-1 induces NAD(P)H oxidase in human endothelial cells. Biochem Biophys Res Commun 269:713-717.

El Khoury J, Hickman SE, Thomas CA, Cao L, Silverstein SC, Loike JD (1996) Scavenger receptor-mediated adhesion of microglia to betaamyloid fibrils. Nature 382:716-719.

El Khoury JB, Moore KJ, Means TK, Leung J, Terada K, Toft M, Freeman MW, Luster AD (2003) CD36 mediates the innate host response to betaamyloid. J Exp Med 197:1657-1666.

Faraci FM (2003) Hyperhomocysteinemia: a million ways to lose control. Arterioscler Thromb Vasc Biol 23:371-373.

Farkas E, de Wilde MC, Kiliaan AJ, Luiten PG (2002) Chronic cerebral hypoperfusion-related neuropathologic changes and compromised cognitive status: window of treatment. Drugs Today (Barc) 38:365-376.

Fuhrman B, Shiner M, Volkova N, Aviram M (2004) Cell-induced copper ion-mediated low density lipoprotein oxidation increases during in vivo monocyte-to-macrophage differentiation. Free Radic Biol Med 37:259-271.

Griendling KK, Minieri CA, Ollerenshaw JD, Alexander RW (1994) Angiotensin II stimulates NADH and NADPH oxidase activity in cultured vascular smooth muscle cells. Circ Res 74:1141-1148.

Guo W, Adachi T, Matsui R, Xu S, Jiang B, Zou MH, Kirber M, Lieberthal W, Cohen RA (2003) Quantitative assessment of tyrosine nitration of manganese superoxide dismutase in angiotensin II-infused rat kidney. Am J Physiol Heart Circ Physiol 285:H1396-H1403.

Hock C, Villringer K, Muller-Spahn F, Wenzel R, Heekeren H, SchuhHofer S, Hofmann M, Minoshima S, Schwaiger M, Dirnagl U, Villringer A (1997) Decrease in parietal cerebral hemoglobin oxygenation during performance of a verbal fluency task in patients with Alzheimer's disease monitored by means of near-infrared spectroscopy (NIRS)-correlation with simultaneous rCBF-PET measurements. Brain Res 755:293-303.

Hossmann KA (1994) Viability thresholds and the penumbra of focal ischemia. Ann Neurol 36:557-565. 
Hsiao K, Chapman P, Nilsen S, Eckman C, Harigaya Y, Younkin S, Yang F, Cole G (1996) Correlative memory deficits, A $\beta$ elevation, and amyloid plaques in transgenic mice. Science 274:99-102.

Huang Z, Huang PL, Ma J, Meng W, Ayata C, Fishman MC, Moskowitz MA (1996) Enlarged infarcts in endothelial nitric oxide synthase knockout mice are attenuated by nitro-L-arginine. J Cereb Blood Flow Metab 16:981-987.

Iadecola C (1992) Nitric oxide participates in the cerebrovasodilation elicited from cerebellar fastigial nucleus. Am J Physiol 263:R1156-R1161.

Iadecola C (2004) Neurovascular regulation in the normal brain and in Alzheimer's disease. Nat Rev Neurosci 5:347-360.

Iadecola C, Niwa K (2002) Nitric oxide. In: Cerebral blood flow and metabolism (Edvinsson L, Krause DN, eds), pp 295-310. Philadelphia: Lippincott, Williams and Wilkins.

Iadecola C, Zhang F, Niwa K, Eckman C, Turner SK, Fischer E, Younkin S, Borchelt DR, Hsiao KK, Carlson GA (1999) SOD1 rescues cerebral endothelial dysfunction in mice overexpressing amyloid precursor protein. Nat Neurosci 2:157-161.

Ischiropoulos H, Beckman JS (2003) Oxidative stress and nitration in neurodegeneration: cause, effect, or association? J Clin Invest 111:163-169.

Jagust WJ (2000) Neuroimaging in dementia. Neurol Clin 18:885-902.

Jones SC, Radinsky CR, Furlan AJ, Chyatte D, Perez-Trepichio AD (1999) Cortical NOS inhibition raises the lower limit of cerebral blood flowarterial pressure autoregulation. Am J Physiol 276:H1253-H1262.

Katusic ZS (2001) Vascular endothelial dysfunction: does tetrahydrobiopterin play a role? Am J Physiol Heart Circ Physiol 281:H981-H986.

Kawarabayashi T, Younkin LH, Saido TC, Shoji M, Ashe KH, Younkin SG (2001) Age-dependent changes in brain, CSF, and plasma amyloid $\beta$ protein in the Tg2576 transgenic mouse model of Alzheimer's disease. J Neurosci 21:372-381.

Lambeth JD (2004) NOX enzymes and the biology of reactive oxygen. Nat Rev Immunol 4:181-189.

Li JM, Shah AM (2004) Endothelial cell superoxide generation: regulation and relevance for cardiovascular pathophysiology. Am J Physiol Regul Integr Comp Physiol 287:R1014-R1030.

Martin KC, Barad M, Kandel ER (2000) Local protein synthesis and its role in synapse-specific plasticity. Curr Opin Neurobiol 10:587-592.

Matsushita K, Kuriyama Y, Nagatsuka K, Nakamura M, Sawada T, Omae T (1994) Periventricular white matter lucency and cerebral blood flow autoregulation in hypertensive patients. Hypertension 23:565-568.

Mentis MJ, Alexander GE, Krasuski J, Pietrini P, Furey ML, Schapiro MB, Rapoport SI (1998) Increasing required neural response to expose abnormal brain function in mild versus moderate or severe Alzheimer's disease: PET study using parametric visual stimulation. Am J Psychiatry 155:785-794.

Mies G, Ishimaru S, Xie Y, Seo K, Hossmann KA (1991) Ischemic thresholds of cerebral protein synthesis and energy state following middle cerebral artery occlusion in rat. J Cereb Blood Flow Metab 11:753-761.

Milekic MH, Alberini CM (2002) Temporally graded requirement for protein synthesis following memory reactivation. Neuron 36:521-525.

Mohazzab KM, Kaminski PM, Wolin MS (1994) NADH oxidoreductase is a major source of superoxide anion in bovine coronary artery endothelium. Am J Physiol 266:H2568-H2572.

Niwa K, Younkin L, Ebeling C, Turner SK, Westaway D, Younkin S, Ashe KH, Carlson GA, Iadecola C (2000a) Abeta 1-40-related reduction in functional hyperemia in mouse neocortex during somatosensory activation. Proc Natl Acad Sci USA 97:9735-9740.

Niwa K, Carlson GA, Iadecola C (2000b) Exogenous A beta1-40 reproduces cerebrovascular alterations resulting from amyloid precursor protein overexpression in mice. J Cereb Blood Flow Metab 20:1659-1668.

Niwa K, Haensel C, Ross ME, Iadecola C (2001a) Cyclooxygenase-1 participates in selected vasodilator responses of the cerebral circulation. Circ Res 88:600-608.

Niwa K, Porter VA, Kazama K, Cornfield D, Carlson GA, Iadecola C (2001b) Abeta-peptides enhance vasoconstriction in cerebral circulation. Am J Physiol Heart Circ Physiol 281:H2417-H2424.

Niwa K, Kazama K, Younkin SG, Carlson GA, Iadecola C (2002a) Alterations in cerebral blood flow and glucose utilization in mice overexpressing the amyloid precursor protein. Neurobiol Dis 9:61-68.

Niwa K, Kazama K, Younkin L, Younkin SG, Carlson GA, Iadecola C (2002b) Cerebrovascular autoregulation is profoundly impaired in mice overex- pressing amyloid precursor protein. Am J Physiol Heart Circ Physiol 283:H315-H323.

Paris D, Humphrey J, Quadros A, Patel N, Crescentini R, Crawford F, Mullan M (2003) Vasoactive effects of A beta in isolated human cerebrovessels and in a transgenic mouse model of Alzheimer's disease: role of inflammation. Neurol Res 25:642-651.

Park L, Anrather J, Forster C, Kazama K, Carlson GA, Iadecola C (2004a) Abeta-induced vascular oxidative stress and attenuation of functional hyperemia in mouse somatosensory cortex. J Cereb Blood Flow Metab 24:334-342.

Park L, Anrather J, Zhou P, Frys K, Wang G, Iadecola C (2004b) Exogenous NADPH increases cerebral blood flow through NADPH oxidasedependent and -independent mechanisms. Arterioscler Thromb Vasc Biol 24:1860-1865.

Parvathenani LK, Tertyshnikova S, Greco CR, Roberts SB, Robertson B, Posmantur R (2003) P2X7 mediates superoxide production in primary microglia and is up-regulated in a transgenic mouse model of Alzheimer's disease. J Biol Chem 278:13309-13317.

Pollock JD, Williams DA, Gifford MA, Li LL, Du X, Fisherman J, Orkin SH, Doerschuk CM, Dinauer MC (1995) Mouse model of X-linked chronic granulomatous disease, an inherited defect in phagocyte superoxide production. Nat Genet 9:202-209.

Prohovnik I, Mayeux R, Sackeim HA, Smith G, Stern Y, Alderson PO (1988) Cerebral perfusion as a diagnostic marker of early Alzheimer's disease. Neurology 38:931-937.

Rey FE, Cifuentes ME, Kiarash A, Quinn MT, Pagano PJ (2001) Novel competitive inhibitor of $\mathrm{NAD}(\mathrm{P}) \mathrm{H}$ oxidase assembly attenuates vascular $\mathrm{O}(2)(-)$ and systolic blood pressure in mice. Circ Res 89:408-414.

Roher AE, Esh C, Kokjohn TA, Kalback W, Luehrs DC, Seward JD, Sue LI, Beach TG (2003) Circle of willis atherosclerosis is a risk factor for sporadic Alzheimer's disease. Arterioscler Thromb Vasc Biol 23:2055-2062.

Roher AE, Esh C, Rahman A, Kokjohn TA, Beach TG (2004) Atherosclerosis of cerebral arteries in Alzheimer disease. Stroke 35:2623-2627.

Rosenblum WI (1987) Hydroxyl radical mediates the endotheliumdependent relaxation produced by bradykinin in mouse cerebral arterioles. Circ Res 61:601-603.

Rosenblum WI, McDonald M, Wormley B (1989) Calcium ionophore and acetylcholine dilate arterioles on the mouse brain by different mechanisms. Stroke 20:1391-1395.

Scheuner D, Eckman C, Jensen M, Song X, Citron M, Suzuki N, Bird TD, Hardy J, Hutton M, Kukull W, Larson E, Levy LE, Viitanen M, Peskind E, Poorkaj P, Schellenberg G, Tanzi R, Wasco W, Lannfelt L, Selkoe D, et al. (1996) Secreted amyloid beta-protein similar to that in the senile plaques of Alzheimer's disease is increased in vivo by the presenilin 1 and 2 and APP mutations linked to familial Alzheimer's disease. Nat Med 2:864-870.

Selkoe DJ, Schenk D (2003) Alzheimer's disease: molecular understanding predicts amyloid-based therapeutics. Annu Rev Pharmacol Toxicol 43:545-584.

Shimohama S, Tanino H, Kawakami N, Okamura N, Kodama H, Yamaguchi T, Hayakawa T, Nunomura A, Chiba S, Perry G, Smith MA, Fujimoto S (2000) Activation of NADPH oxidase in Alzheimer's disease brains. Biochem Biophys Res Commun 273:5-9.

Sobey CG, Faraci FM (1997) Effects of a novel inhibitor of guanylyl cyclase on dilator responses of mouse cerebral arterioles. Stroke 28:837-843.

Soriano FG, Virag L, Szabo C (2001) Diabetic endothelial dysfunction: role of reactive oxygen and nitrogen species production and poly(ADPribose) polymerase activation. J Mol Med 79:437-448.

Stamler JS (1996) A radical vascular connection. Nature 380:108-111.

Stewart R, Cai H, Harrison DG, Rothe G, Valet G (1998) Cardiovascular factors in Alzheimer's disease. J Neurol Neurosurg Psychiatry 65:143-147.

Thomas T, Thomas G, McLendon C, Sutton T, Mullan M (1996) $\beta$-Amyloid-mediated vasoactivity and vascular endothelial damage. Nature 380:168-171.

Van Dijk EJ, Prins ND, Vermeer SE, Hofman A, Van Duijn CM, Koudstaal PJ, Breteler MM (2004) Plasma amyloid beta, apolipoprotein E, lacunar infarcts, and white matter lesions. Ann Neurol 55:570-575.

Wautier MP, Chappey O, Corda S, Stern DM, Schmidt AM, Wautier JL (2001) Activation of NADPH oxidase by AGE links oxidant stress to 
altered gene expression via RAGE. Am J Physiol Endocrinol Metab 280:E685-E694.

Yan SD, Chen X, Fu J, Chen M, Zhu H, Roher A, Slattery T, Zhao L, Nagashima M, Morser J, Migheli A, Nawroth P, Stern D, Schmidt AM (1996) RAGE and amyloid-beta peptide neurotoxicity in Alzheimer's disease. Nature 382:685-691.

Yang G, Iadecola C (1997) Obligatory role of NO in glutamate-dependent hyperemia evoked from cerebellar parallel fibers. Am J Physiol 272:R1155-R1161.

Yang G, Chen G, Ebner TJ, Iadecola C (1999) Nitric oxide is the predominant mediator of cerebellar hyperemia during somatosensory activation in rats. Am J Physiol 277:R1760-R1770.

Yang G, Zhang Y, Ross ME, Iadecola C (2003) Attenuation of activity- induced increases in cerebellar blood flow in mice lacking neuronal nitric oxide synthase. Am J Physiol Heart Circ Physiol 285:H298-H304.

Zhang F, Eckman C, Younkin S, Hsiao KK, Iadecola C (1997) Increased susceptibility to ischemic brain damage in transgenic mice overexpressing the amyloid precursor protein. J Neurosci 17:7655-7661.

Zheng JS, Yang XQ, Lookingland KJ, Fink GD, Hesslinger C, Kapatos G, Kovesdi I, Chen AF (2003) Gene transfer of human guanosine 5' -triphosphate cyclohydrolase I restores vascular tetrahydrobiopterin level and endothelial function in low renin hypertension. Circulation 108:1238-1245.

Zou MH, Leist M, Ullrich V (1999) Selective nitration of prostacyclin synthase and defective vasorelaxation in atherosclerotic bovine coronary arteries. Am J Pathol 154:1359-1365. 